\title{
1 QUESTÃo FEDERATIVA E A
REFORMA FISCAL
}

Fundação Getúlio Vargas - FGV*

\section{Objetivo}

D

ar transparência e confiabilidade à análise do impacto de propostas de Reforma Fiscal, do ponto de vista de suas implicações regionais e federativas, com o propósito de subsidiar a negociação política necessária à aprovação de uma Reforma, cuja amplitude e profundidade esteja de acordo com reclamos $e$ as expectativas dos mais distintos segmentos da sociedade brasileira.

\section{Justificativa}

em sido cabalmente demonstrado, nos últimos anos, que a decantada Reforma Fiscal não carece de boas idéias e nem da formulação de propostas consistentes. Inú meras Comissóes encarregadas da claboração de projetos a respeito, no âmbito do Executivo e do Legislativo, desempenharam a contento a tarefa para a qual foram constituidas. Entidades de classe, profissionais liberais e especialistas na matéria têm divulgado, com insistência, preciosas recomendaçōes a respeito.
Incon táveis congressos, reuniōes e seminários têm sido organizados em todo o país, para debater este tema. Não obstante toda essa mobilização, perdura o impasse que tem impedido a obtençāo de resultados concretos a respeito. Cada tentativa de Reforma acaba produzindo mais um mal feito remendo.

A questão federativa $\mathrm{c}$ os interesses regionais estāo no ceme dos conflitos de interesses de cuja soluçâo depende a obienção de resultados satisfatórios no terreno da Reforma Fiscal. Não adianta in. sistir na tese de que a Constituiçao de 1988 provocou um desequilibrio na repartição de recursos ao redistribuir as receitas sem fazer o mesmo com os encargos. A raiz do impasse está na ausência de um prévio entendimento sobre um novo modelo de federalismo fiscal que leve em conta a redefin ição do papel do Estado c as exigências de racionalizaçāo do sistema tributário, de integração competitiva da cconomia brasilcira ao mundo moderno, e de enfrentamento das enormes disparidades regionais c sociais.

A negociação das propostas de Reforma Fiscal à luz dos interes- 
ses federativos e regionais padece de um grave problema: a falta de confiabilidade das análises que são feitas para demonstrar o resultado esperado das diversas alternativas conhecidas. Como se sabc, o impasse surge da análise dos números. De um lado, a precaricdade da base estatistica sobre a qual assentam-se as previsōes de impacto de projetos de Reforma Fiscal levanta sérias suspeitas sobre os resultados anunciados. De outro, a utilização de procedimentos metodológicos distintos, mais adequados aos particulares interesses de cada uma das partes en volvidas, contribui para resultados que, em alguns casos, chegam a ser absolutamente divergentes. $\mathbf{A}$ múlua desconfiança nos números que cada parte trà à mesa de negociaçóes inibe o avanço de qualquer proposta que acarrete modificaçōes na estrutura tributária vigen1c. Não é por acaso que a mais recente tentativa nesse campo terminou com um acordo que se resumiu à criação de um novo tribu to.

A confiabilidade das estimativas de impacio da Reforma Fiscal pretendida é fundamental para o avanço das negociaçōes. Para tan10, é indispensável iniciar um trabalho de harmonização de metodologias e de unificação da base cstatistica utilizada na quantificação. Esssa não é, todavia, uma tarefa a ser feita isoladamente. Para ser bem sucedida ela requer um esforço conjunto dos principais atores que têm influência decisiva no desfecho do progresso de Reforma Fiscal. A presente proposta visa criar as condiçōes necessárias para a execução da tarefa pretendida.

\section{Conteúdo}

ão se trata de claborar novas propostas, mas sim de avaliar alternativa que permite conciliar os objetivos de simplificação e racionalização do sistema tributário brasileiro com as exigências de recquilibrio do sistema federativo e de redução das disparidades regionais. O menu de opçōes contido nos vários projetos de limenda Constitucional ao capítulo tributário da Constituição já submetidos ao Congresso Nacional ć bastante variado. Trata-se, assim, de trabalhar na linha de um entendimento comum sobre méritos das propostas conhecidas, buscando construir a alternativa que minimize os conflitos que têm impedido, atć agora, aprovaçāo de uma cfetiva Reforma Fiscal.

Assim, o trabalho a ser realizado contempla:

a) a organização de um banco de dados comum para a análise do impacto das propostas de Reforma Fiscal;

b) o livre acesso de todas as partes interessadas a este banco de dados;

c) a análise dos procedimentos metodológicos utilizados nas esti- 
mativas dos impactos das alternativas de Reforma;

d) a busca de uma metodologia aceita pela maioria das partes, para proceder à referida avaliação;

e) a busca de uma solução factivel para o problema da descentralìação de encangos;

f) o mapeamento dos conflitos e a identificação das mangens de manobra que podem facilitar a indispensável negoxiação.

\section{Execução}

execução do trabalho proposto requer a organização de um grupo técnico, de caráter permanente (até a conclusão da revisão constitucional), composto por profissionais ligados ao Congresso $\mathrm{Na}$ cional, ao Poder Executivo da Uniāo, cstados c municípios, a instituições de pesquisa e a entidades que congregam empresários e trabalhadores. O grupo será formado por técn icos de reconhecida experiência na área fiscal. As atividades desse grupo serão coordenadas por uma reduzida equipe de consultores, a ser especialmente constituida para esse fim, $\mathrm{c}$ poderão contar com a participação eventual de outros profissionais.

O grupo reunir-se-á, ordinariamente, uma vez por mês para analisar os assuntos sugeridos em pauta previamente claborada pelos consultores-coordenadores.
Rcunióes extraordinárias serão convocadas quando necessário.

Cada participante do grupo deverá contar com o apoio das respectivas instituições para executar as tarefas acordadas cm cada reuniāo. Caberá à coordenaçāo do projeto a tarefa de organizar c conduzir as reuniōes e desen volver as demais atividades necessárias ao bom andamento dos trabalhos. O resultado do trabalho será reunido pelo grupo de coordenação e disseminado en tre todos os interessados sob a forma de notas.
* Realização: Escola Brasileira de Administraçāo Pública EBAP/ FVG (pesquisador: Fernando Rezende). 